\title{
Unusually Large von Willebrand Factor Multimers Increase Adhesion of Sickle Erythrocytes to Human Endothelial Cells under Controlled Flow
}

\author{
Timothy M. Wick, „ Joel L. Moake, ${ }^{\star 5}$ Mark M. Udden, Suzanne G. Eskin," David A. Sears, \\ *Biomedical Engineering Laboratory, Department of Chemical Engineering, Rice University, Houston, Texas 77251; \\ ${ }^{\dagger}$ Medical Hematology Section, The Methodist Hospital, Houston, Texas 77030; and ${ }^{\S}$ Department of Medicine and \\ "Department of Surgery, Baylor College of Medicine, Houston, Texas 77030
}

\begin{abstract}
The interactions of normal erythrocytes and erythrocytes from patients having hemoglobin $S$ hemoglobinopathies with normal human endothelial cells (EC) were investigated under flow conditions. When EC supernatant, containing 2.8-11.0 U/dl of von Willebrand factor (vWF) antigen and vWF multimeric forms larger than those present in normal plasma, was the red blood cell (RBC)-suspending medium instead of serum-free medium (SFM), the adhesion of sickle RBC, but not normal RBC, to endothelial cells was greatly increased (range of enhancement of sickle RBC adhesion, 2- to 27-fold). Adhesion of sickle $\mathbf{R B C}$ to endothelial cells was reduced to near serum-free levels when EC supernatant was immunologically depleted of vWF forms. Sickle RBC suspended in SFM containing 200 $U / d l$ of purified $\mathbf{v W F}$ multimers of the type found in normal human plasma or $300 \mu \mathrm{g} / \mathrm{ml}$ human fibronectin were only slightly more adhesive to endothelial cells than sickle RBC suspended in SFM alone.

These data indicate that unusually large vWF multimers produced by endothelial cells are potent mediators of the adhesion of sickle erythrocytes to endothelial cells. Vaso-occlusive crises in sickle cell anemia may be caused, at least in part, by adhesive interactions between the abnormal surfaces of sickle $R B C$ and the endothelium after the release of unusually large vWF multimeric forms from stimulated or damaged endothelial cells.
\end{abstract}

\section{Introduction}

The major manifestations of sickle cell anemia are periodic, localized, vaso-occlusive crises and chronic hemolytic anemia. Adhesion of sickle erythrocytes to the vascular endothelium has been proposed as one mechanism of vaso-occlusion (1-6). This investigation was undertaken to determine the role of von

Address correspondence to Dr. Larry V. McIntire, Biomedical Engineering Laboratory, Department of Chemical Engineering, Rice University, Houston, TX 77251.

Received for publication 23 January 1987 and in revised form 27 May 1987.

J. Clin. Invest.

(c) The American Society for Clinical Investigation, Inc. 0021-9738/87/09/0905/06 \$2.00

Volume 80, September 1987, 905-910
Willebrand factor $(\mathrm{vWF})^{1}$ in the adhesive interactions between sickle erythrocytes and endothelial cells.

$\mathrm{vWF}$ is a large, multimeric plasma protein (subunit molecular weight of $2.20 \times 10^{5} \mathrm{D}$ [7]) synthesized by megakaryocytes (8) and endothelial cells (9). The circulating pool of vWF is heterogeneous with multimers ranging from $8.5 \times 10^{5}$ to millions of daltons (10). Large vWF multimeric forms are involved in platelet-subendothelial adhesion (11) and in shear stress-induced platelet aggregation (12). Large vWF forms bind to platelet membranes via glycoprotein $\mathrm{Ib}(13,14)$ and IIb/IIIa complexes $(15,16)$. Arginine-glycine-aspartate amino acid sequences are involved in the binding of vWF to the IIb/IIIa complexes $(17,18)$.

Human endothelial cells (EC) in culture synthesize vWF multimers which are larger than the largest multimeric forms found in normal human plasma (19). These unusually large vWF forms are secreted by endothelial cells into the subendothelial matrix (20) and, under conditions of intense endothelial cell stimulation, into the plasma (21).

Human endothelial cells also produce and secrete fibronectin (22), another important cytoadhesive protein (23). It has been demonstrated that red cells of patients with sickle cell disease bind fibronectin in greater quantities than normal erythrocytes (24), and therefore fibronectin may be another important mediator of erythrocyte/endothelial cell interactions.

Microvascular occlusion in sickle cell anemia may be caused in part by capillary blockage with rigid, irreversibly sickled cells $(25,26)$. Deoxygenation of hemoglobin $S$ in sickle red cells may lead to a cycle of tissue ischemia, sickling, and vaso-occlusion (26). However, recent observations (1-6) have suggested that adherence of sickle erythrocytes to the vascular endothelium may be a complementary or alternative mechanism of vaso-occlusion. Under both static (1-5) and flow (6) conditions sickle red cells adhere abnormally to cultured endothelial cells. This increase in adhesion, when compared with normal red cells, has been related to the clinical severity of vaso-occlusive events in sickle cell disease (3). Mohandas et al. (4), using a quantitative micropipette technique, demonstrated that adhesion observed in vitro could occur under the fluid forces present in the microcirculation, implying that sickle erythrocytes could also be more adhesive in vivo. We have

1. Abbreviations used in this paper: EC, endothelial cell; FN, fibronectin; IRMA, immunoradiometric assay; RBC, red blood cell; SFM, serum-free medium; vWF, von Willebrand factor. 
investigated the mechanism of adhesion between sickle red cells and normal human endothelial cells.

\section{Methods}

Endothelial cell cultures. Umbilical cords were obtained from the $\mathrm{Ob}$ stetrics Service of Jefferson Davis Hospital, Houston, TX. The umbilical veins were cannulated and rinsed with $100 \mathrm{ml}$ of sterile, $37^{\circ} \mathrm{C}$ phosphate buffer $(0.14 \mathrm{M} \mathrm{NaCl}, 0.0004 \mathrm{M} \mathrm{KCl}, 0.011 \mathrm{M}$ glucose, $0.00022 \mathrm{M} \mathrm{NaH}_{2} \mathrm{PO}_{4}$, and $\left.0.0081 \mathrm{M} \mathrm{Na}_{2} \mathrm{HPO}_{4}\right)$. Veins were filled with $12 \mathrm{mg}$ collagenase ( $169 \mathrm{U} / \mathrm{mg}$; Cooper Biomedical, Inc., Malvern, PA) dissolved in $50 \mathrm{ml}$ of $37^{\circ} \mathrm{C}$ phosphate-buffered saline (PBS; $0.0027 \mathrm{M}$ $\mathrm{KCl}, 0.0015 \mathrm{M} \mathrm{KH}_{2} \mathrm{PO}_{4}, 0.137 \mathrm{M} \mathrm{NaCl}, 0.0081 \mathrm{M} \mathrm{Na}_{2} \mathrm{HPO}_{2} \cdot 7 \mathrm{H}_{2} \mathrm{O}$, and $0.00049 \mathrm{M} \mathrm{MgCl}_{2}$; Gibco, Grand Island, NY) and incubated for $30 \mathrm{~min}$. The collagenase suspensions were collected, and the veins were rinsed with $100 \mathrm{ml}$ of phosphate buffer to ensure collection of all cells. Effluent was centrifuged for $10 \mathrm{~min}$ at $100 \mathrm{~g}$ and the cell pellets were resuspended in complete medium (M199, Gibco; with 20\% heat-inactivated fetal calf serum, HyClone Laboratories, Logan, UT; 0.10 $\mathrm{mg} / \mathrm{ml}$ penicillin and streptomycin, Gibco; $0.20 \mathrm{mg} / \mathrm{ml}$ neomycin, Gibco; $0.292 \mathrm{mg} / \mathrm{ml}$ glutamine, Gibco). Cells from different cords were pooled and seeded onto $75 \mathrm{~mm} \times 38 \mathrm{~mm}$ glass slides (Fisher Scientific, Springfield, NJ) pretreated with $0.5 \mathrm{~N} \mathrm{NaOH}$ for 2 hours to improve surface properties. Cells were grown to confluence (2-4 days) in a $37^{\circ} \mathrm{C}$ incubator $\left(5 \% \mathrm{CO}_{2}\right)$ and were then used within three days.

Endothelial cell supernatants. Endothelial cells were cultured to confluence in complete medium. Monolayers were rinsed twice in PBS $\left(37^{\circ} \mathrm{C}\right.$ ), coated with $2 \mathrm{ml}$ of serum-free medium (SFM; containing 5.0 $\mu \mathrm{g} / \mathrm{ml}$ bovine insulin, Sigma Chemical Co., St. Louis, MO; $5.0 \mu \mathrm{g} / \mathrm{ml}$ human transferrin, Sigma Chemical Co., 0.4\% human albumin, Sigma Chemical Co., $0.10 \mathrm{mg} / \mathrm{ml}$ penicillin and streptomycin; $0.20 \mathrm{mg} / \mathrm{ml}$ neomycin; $0.292 \mathrm{mg} / \mathrm{ml}$ glutamine in $\mathrm{M} 199)$, and incubated at $37^{\circ} \mathrm{C}$ for $48 \mathrm{~h}$. The supernatant was then removed and contained between 2.8 and $11.0 \mathrm{U} / \mathrm{dl}$ of vWF antigen (normal platelet-poor plasma contains $100 \mathrm{U} / \mathrm{dl}$ of vWF antigen). In some experiments, EC supernatant was depleted of vWF forms by incubation with rabbit anti-human vWF antibody linked to Protein-A Sepharose CL-4B (Pharmacia, Inc., Piscataway, NJ) for $2 \mathrm{~h}$ at room temperature. The vWF antibody did not cross-react with fibronectin. Cultures used to produce EC supernatant were not used in the red cell adhesion assays.

Purification of $v W F$. Human vWF multimeric forms were purified from blood bank cryosupernatant and fractionated as described previously (27).

Red cell suspensions. Blood was drawn from normal donors or patients with sickle hemoglobinopathies (HbSS, HbSC, sickle cell $\beta$ thalassemia) into sodium heparin (14.3 USP units/ml), centrifuged at $100 \mathrm{~g}$ for $10 \mathrm{~min}$, and the plasma and buffy coat were removed and discarded. The red cells were washed three times in SFM and resuspended in either SFM, EC supernatant, or EC supernatant depleted of vWF. Our experiments were designed to elucidate a possible mechanism of adhesion and not to reproduce in vivo conditions. Therefore, a hematocrit of $1 \%$ was chosen to limit the amount of blood required from each donor for each experiment. For red cell adhesion assays in the presence of plasma proteins, either fibronectin (purified from human plasma; Sigma Chemical Co.) was added to SFM to produce a final concentration of $300 \mu \mathrm{g} / \mathrm{ml}$ or purified plasma vWF enriched in the largest multimeric forms found in the cryoprecipitate fraction of normal human plasma was added to a final concentration of $200 \mathrm{U} / \mathrm{dl}$. Red cells suspended in SFM, EC supernatant, or EC supernatant depleted of vWF were not morphologically altered in the various suspending media when observed under phase contrast $(200 \times)$ or oil immersion light microscopy $(1,000 \times)$ after fixation in gluteraldehyde.

Adhesion assay. Confluent endothelial monolayers on glass slides made up the base of a modified Richardson flow chamber (Fig. 1) held in place by an applied vacuum. The chamber, with slide of endothelial cells in place, was mounted on the stage of an inverted, phase-contrast

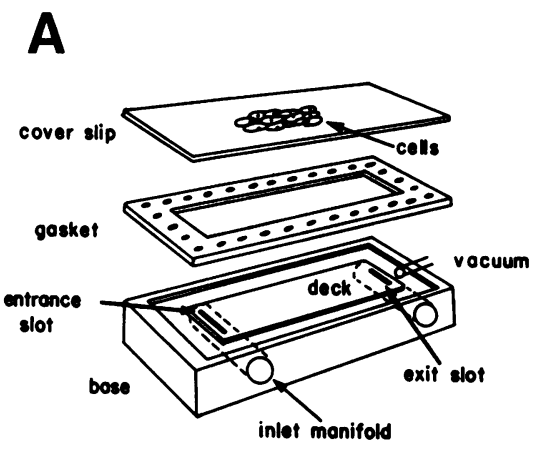

\section{B}

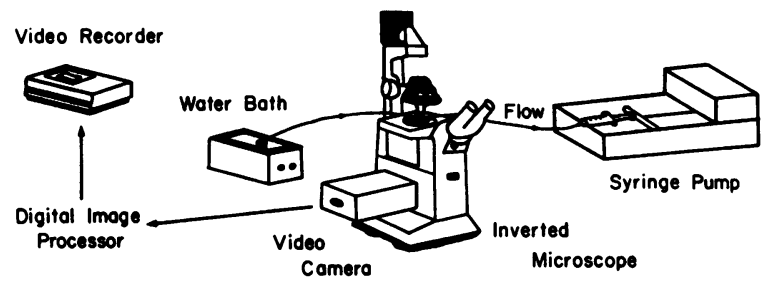

Figure 1. Adhesion assay apparatus. (A) An EC monolayer on a glass slide forms the base of the flow chamber and is held in place by a vacuum applied at the vacuum port. The depth of the parallel-plate flow chamber is determined by the thickness of the gasket, and for the experiments reported is $104 \mu$. (B) The chamber, with EC monolayer in position, is inverted and mounted on the microscope stage. Media and red cell suspensions are kept in an adjacent $37^{\circ} \mathrm{C}$ water bath and flow over the EC monolayer at a rate of $0.0764 \mathrm{ml} / \mathrm{min}$ (wall shear stress, $1.0 \mathrm{dyn} / \mathrm{cm}^{2}$ ) by use of the syringe pump. The EC monolayer is kept at $37^{\circ} \mathrm{C}$ by an air curtain incubator mounted on the microscope (not shown). A video camera and video cassette recorder are mounted on the microscope to facilitate red cell counting and to record experiments for later analysis.

microscope (Nikon). Medium and red cell suspensions were kept at $37^{\circ} \mathrm{C}$ in an adjacent water bath and the chamber was maintained at $37^{\circ} \mathrm{C}$ by an air curtain incubator.

The endothelial cell monolayer was rinsed for $5 \mathrm{~min}$ with SFM at a constant flow rate of $0.0764 \mathrm{ml} / \mathrm{min}$ generated by a Harvard syringe pump producing a wall shear stress of $1.0 \mathrm{dyn} / \mathrm{cm}^{2}$ (a shear stress typically found in the venules [28]). The red cell suspension was then passed over the endothelial cell monolayer for $10 \mathrm{~min}$ followed by a 20 -min rinse with SFM to remove nonadherent red cells. Even at $1 \%$ hematocrit, the endothelial cell monolayer was entirely covered with red cells for the entire 10 min of perfusion, and thus many of the cells were able to interact with the endothelial surface. Therefore, the adhesion values observed were an accurate representation of the adhesive subfraction of each donor's erythrocytes. No static incubation of red cells on the endothelial cell monolayer occurred before rinsing began. The number of adherent cells was counted in 24 random fields ranging over the entire slide.

$v W F$ antigen level. vWF antigen was quantified by solid-phase immunoradiometric assay (IRMA) using rabbit anti-human vWF antibody and rabbit [ $\left.{ }^{125} \mathrm{I}\right]$-anti-human vWF antibody as previously described (29).

$v W F$ multimer patterns. vWF multimers were separated by sodium dodecyl sulfate agarose gel electrophoresis, overlaid with [ $\left.{ }^{125} \mathrm{I}\right]$-antihuman vWF IgG and analyzed by autoradiography using $1 \%$ agarose and a continuous buffer system $(30,31)$.

Fibronectin antigen level. Fibronectin antigen was quantified by 
Laurell 'rocket' immunoelectrophoresis as previously described (32).

Statistics. The data for each donor were analyzed using an F-test (33), which distinguishes between the field-to-field variance and the treatment variance (EC supernatant vs. SFM, EC supernatant vs. vWF-depleted EC supernatant, etc.).

\section{Results}

The EC supernatants contained relatively small amounts of vWF antigen (2.8-11.0 U/dl), but a major component of the multimers were unusually large forms not found in normal pooled plasma (Fig. 2). The endothelial cell supernatants also contained small amounts of fibronectin $(<20 \mu \mathrm{g} / \mathrm{ml})$. This fibronectin was present in the supernatants even after they were depleted of vWF (data not shown).

The adhesion of normal red cells ranged from 2.52 to 4.08 $\mathrm{RBC} / \mathrm{mm}^{2}$ in SFM and increased slightly to 4.17-5.81 RBC/ $\mathrm{mm}^{2}$ in EC supernatant (Table I). The adhesion of sickle red cells suspended in SFM to endothelial cells was 3.04-10.24 $\mathrm{RBC} / \mathrm{mm}^{2}$, and increased greatly to $12.76-132.12 \mathrm{RBC} / \mathrm{mm}^{2}$ when the sickle red cells were suspended in EC supernatant (average 11-fold increase; range 2- to 27-fold for eight experiments with six different patients, Table I). When the EC supernatant was immunologically depleted of vWF multimers, the adhesion of sickle red cells decreased to nearly the SFM control level (3.13-9.81 $\left.\mathrm{RBC} / \mathrm{mm}^{2}\right)$. The antigen level in the vWF-depleted EC supernates was $<1.5 \mathrm{U} / \mathrm{dl}$ for the four patients studied (column 3, Table I). Fig. 3 shows an endothelial cell monolayer before and after the 10-min perfusion of sickle erythrocytes in EC supernatant.

When fibronectin (FN) or purified plasma vWF were added to a suspension of sickle red cells (HbSS or HbSC) in SFM $(300 \mu \mathrm{g} / \mathrm{ml} \mathrm{FN} \mathrm{or} 200 \mathrm{U} / \mathrm{dl}$ of the largest vWF multimers found in cryoprecipitate), the extent of adhesion to the endothelial monolayers increased only modestly (Table II). The enhancement with either FN or VWF was 1.5- to 2.5-fold, much less than the enhancement of sickle erythrocyte adhesion to endothelial cells in the presence of endothelial cell supernatant.

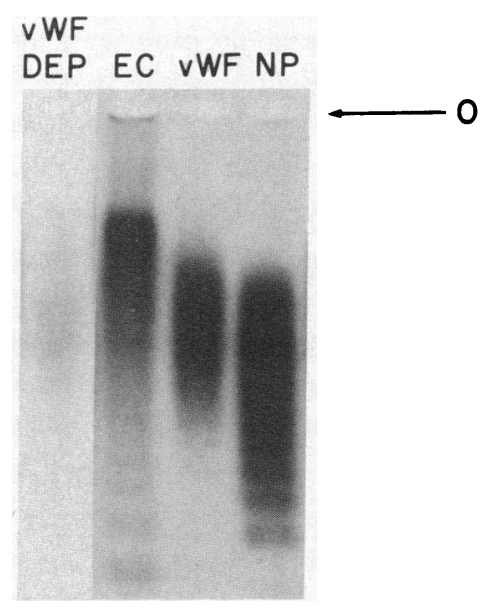

Figure 2. vWF multimer patterns of test samples. vWF multimers were separated by sodium dodecyl sulfate- $1 \%$ agarose gel electrophoresis. $v W F$, sample of VWF multimers purified from the cryoprecipitate fraction of normal plasma, including largest multimeric forms found in normal plasma. $E C$, sample of endothelial cell supernatant containing unusually large vWF multimers not found in $N P$. $v W F D E P$, EC supernatant preparation immunologically depleted of

vWF forms. $N P$, sample of normal pooled, platelet-poor plasma, shown for comparison.
Table I. Adhesion of Sickle and Normal Red Blood Cells to Endothelial Cells

\begin{tabular}{|c|c|c|c|}
\hline & $\begin{array}{l}\text { Adhesion in } \\
\text { SFM }\end{array}$ & Adhesion in EC SUP & $\begin{array}{l}\text { Adhesion in vWF } \\
\text { DEP-EC SUP }\end{array}$ \\
\hline \multicolumn{4}{|c|}{$\begin{array}{l}\text { Normal red cells } \\
\text { (HbAA) }\end{array}$} \\
\hline Donor 1 & $2.52 \pm 3.19$ & $5.73 \pm 6.41(P<0.01)$ & \\
\hline Donor 2 & $4.08 \pm 4.16$ & 4.17 $\pm 4.71(P=\mathrm{NS})$ & \\
\hline Donor 3 & $3.47 \pm 4.96$ & $5.03 \pm 4.07(P=N S)^{*}$ & \\
\hline Donor 4 & $2.69 \pm 3.38$ & $5.81 \pm 7.28(P<0.01)$ & \\
\hline \multicolumn{4}{|c|}{$\begin{array}{l}\text { Sickle red cells } \\
\text { (HbSS) }\end{array}$} \\
\hline Patient 1 & $5.73 \pm 4.91$ & $19.10 \pm 11.38^{8}$ & 一 \\
\hline Patient 2 & $10.24 \pm 6.37$ & $68.92 \pm 37.37^{6}$ & - \\
\hline Patient 3 & $3.23 \pm 3.06^{\ddagger}$ & $35.21 \pm 15.70^{5}$ & - \\
\hline Patient 4 & $3.04 \pm 4.19 \neq$ & $83.33 \pm 56.86^{8}$ & - \\
\hline Patient 5 & $5.90 \pm 5.22$ & $35.94 \pm 24.43^{6}$ & $3.13 \pm 5.40^{\prime}$ \\
\hline Patient 6 & $4.95 \pm 4.84$ & $30.96 \pm 17.01^{\text {볘 }}$ & $9.81 \pm 7.66^{\prime}$ \\
\hline Patient 7 & $6.16 \pm 5.08$ & $12.76 \pm 5.98^{5}$ & $5.38 \pm 5.30^{\prime}$ \\
\hline Patient 8 & $5.12 \pm 4.65^{\ddagger}$ & $132.12 \pm 45.74^{8}$ & $8.77 \pm 9.85^{\prime}$ \\
\hline
\end{tabular}

Adhesion $\left(\mathrm{RBC} / \mathrm{mm}^{2}\right.$ ) to human endothelial cell monolayers of washed red cells from normal donors and patients with sickle cell anemia resuspended in serum-free medium (SFM), human endothelial cell supernatant (EC SUP) containing unusually large vWF multimers, or EC supernatant depleted of vWF (vWF-DEP EC SUP). The values are mean \pm SD reflecting the variation of the 24 fields viewed and counted per slide.) $(n=48$ fields analyzed, except where noted.

$* n=24$.

* Same donor studied on different days. This patient has sickle cell $\beta$-thalassemia.

Increase in sickle RBC adhesion in EC SUP column compared with SFM column $(P<0.001)$.

" $n=72$.

' Decrease in sickle RBC adhesion in vWF DEP-EC SUP column compared with EC SUP column $(P<0.001)$.

\section{Discussion}

EC supernatant contains only small quantities $(<12 \mathrm{U} / \mathrm{dl})$ of vWF antigen. However, it includes unusually large vWF multimeric forms. EC supernatant, but not the largest vWF forms purified from cryoprecipitate, greatly increased the adherence of sickle erythrocytes to cultured human endothelial cells (Tables I and II). In contrast, only a slight augmentation of EC adhesion by the unusually large vWF forms of EC supernatant was observed for normal RBC (Table I). In the absence of the unusually large vWF multimeric forms, even a high concentration of vWF antigen ( $200 \mathrm{U} / \mathrm{dl})$, containing the largest multimeric forms purified from the cryoprecipitate fraction of normal plasma, caused only a modest increase in the adhesion to endothelial cells of $\mathrm{HbSS}$ and HbSC RBC compared with increases observed in the presence of unusually large vWF multimers. The addition of fibronectin to sickle red cells suspended in SFM at $300 \mu \mathrm{g} / \mathrm{ml}$ also resulted in only small increases in adhesion (Table II) compared with the unusually large vWF. These data indicate that the unusually large vWF multimers derived from endothelial cells are optimally effective in promoting the binding of sickle red cells to endothelial cells.

The levels of fibronectin and vWF factor in normal pooled platelet-poor plasma are $300 \mu \mathrm{g} / \mathrm{ml}$ and $100 \mathrm{U} / \mathrm{dl}$, respectively. The plasma fibronectin level remains relatively constant with time in both normal and sickle patients (34). This is not the 

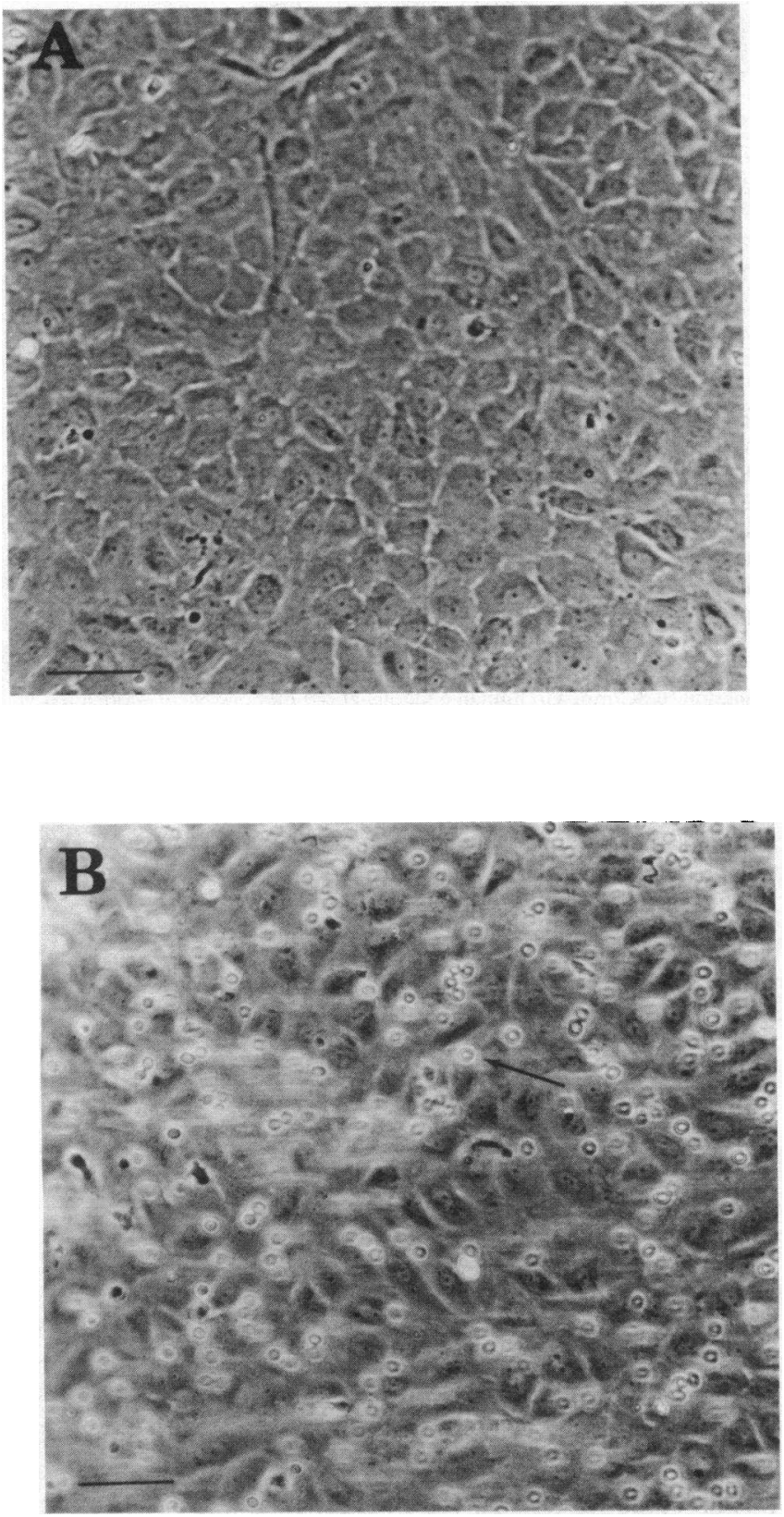

Figure 3. Adhesion of sickle red blood cells to endothelial cells. $(A)$ EC monolayer being rinsed for $5 \mathrm{~min}$ by SFM before perfusion of sickle red cells. Flow is from left to right. Bar, $50 \mu$. (B) EC monolayer after 10-min perfusion of sickle red cells suspended in EC supernatant and a 20-min rinse to remove nonadherent cells with SFM. Arrow points to one of the many adherent red cells in this field. Flow is from left to right. Bar, $50 \mu$. Streaks are nonadherent cells flowing with the perfusion medium.

case with vWF antigen levels, which often increase in times of crises (35), suggesting that endothelial cell stimulation or damage occurs during these clinical events.

In two preliminary experiments, addition of $6.81 \times 10^{-8} \mathrm{M}$ of the tetrapeptide Arg-Gly-Asp-Ser to sickle red cells suspended in EC supernatant (a molar concentration 100 times that of plasma fibronectin) decreased by $99 \%$ the binding of
Table II. Effect of Plasma Proteins on Adhesion of Sickle RBC to Endothelial Cells

\begin{tabular}{llrr}
\hline & Adhesion in SFM & $\begin{array}{l}\text { Adhesion in } \\
\text { SFM + FN }\end{array}$ & $\begin{array}{l}\text { Adhesion in SFM } \\
\text { + Plasma vWF }\end{array}$ \\
\hline Patient 1 & $7.29 \pm 5.33$ & $12.76 \pm 6.62$ & $15.71 \pm 6.56$ \\
Patient 2 & $3.47 \pm 3.37$ & $5.64 \pm 3.70$ & $6.33 \pm 3.84$ \\
Patient 3 & $1.39 \pm 2.16$ & $3.47 \pm 2.76$ & $2.43 \pm 2.96$
\end{tabular}

Adhesion of washed red cells $\left(\mathrm{RBC} / \mathrm{mm}^{2}\right)$ from patients with sickle cell syndromes resuspended in SFM to human endothelial cell monolayers. The largest plasma forms of vWF (200 U/dl) and/or human FN $(300 \mu \mathrm{g} / \mathrm{ml})$ were added as indicated. The values are mean \pm SD reflecting the variation of 24 fields viewed and counted per slide (48 total fields analyzed for each trial). Both columns were significantly different $(P<0.01)$ from the SFM adhesion column. Patients 1 and 2 had sickle cell anemia (HbSS) and patient 3 had HbSC disease.

sickle red blood cells to endothelial cells that was mediated by the unusually large vWF multimers. Red cells from sickle patients 5 and 8 (Table I) were incubated in the EC supernates containing the peptide for $30 \mathrm{~min}$ and analyzed for adhesion in the flow chamber as previously described. Adhesion of the red cells suspended in EC supernatant decreased from $35.94 \pm 24.43$ to $6.16 \pm 6.55 \mathrm{RBC} / \mathrm{mm}^{2}$ and from $132.12 \pm 45.74$ to $6.68 \pm 6.75 \mathrm{RBC} / \mathrm{mm}^{2}$ for patients 5 and 8 , respectively, in the presence of the peptide. The observed adhesion values in the presence of the peptide were not significantly different from the adhesion values in the SFM control experiments for each of the donors. Thus, either the endothelial cells or the sickle red blood cells have binding sites similar to the glycoprotein IIb/IIIa complex in platelets that were able to recognize the Arg-Gly-Asp-Ser sequences in unusually large vWF multimeric forms. That type of binding site has recently been demonstrated in erythroleukemia cells (36) as well as in human endothelial cells (37). It has also been reported recently that human endothelial cells contain receptors similar to glycoprotein Ib (38), the other binding site for large vWF forms on human platelets.

Sickle red cells, in contrast to normal red cells, may have incipient receptors for vWF on their surface because they are relatively young cells, or because of alterations in their membrane structure induced by cycles of $\mathrm{HbS}$ polymerization-depolymerization in conjunction with shear forces in the blood. Shear forces have been shown to effect the exposure or topography of platelet surface receptors for large and unusually large vWF multimers (12).

Sickle cell disease is characterized clinically as a pathologic red cell alteration leading to periodic, localized, vaso-occlusive crises. These crises often occur in conjunction with increased stress, vigorous exercise, infection, or pregnancy, which may lead to mechanical or chemical stimulation of endothelial cells. Endothelial cell stimulation could occur in the region of the microcirculation where the small capillary diameter allows for intimate contact of closely apposed red cells and endothelial cells. Here, mechanical stimulation or lysis of endothelial cells could even be provoked by direct contact with rigid, sickled erythrocytes. Our data suggest that unusually large vWF multimers mediate the adhesion of sickle RBC to endothelial 
cells and contribute to vaso-occlusive episodes. These episodes may occur when endothelial cells are intensely stimulated to release their content of unusually large vWF from Weibel-Palade bodies. Locally high concentrations of unusually large vWF multimers (in excess of the capacity of plasma to process or remove these huge forms [39]) may result in the concurrent binding of unusually large vWF multimers to sickle RBC and endothelial cells. The bonds formed may be strong enough to withstand the fluid shear forces in the microcirculation, or at least those forces in the postcapillary venules simulated in our experiments. Vaso-occlusion may then occur, with adherent sickle red cells combining locally with the most dense, irreversibly sickled RBC to occlude portions of the microvascular circulation in a cycle of lengthened transit times, deoxygenation, HbS polymerization, unusually large vWF-mediated sickle RBC attachment to the endothelium, and vascular obstruction.

\section{Acknowledgments}

We appreciate the technical contributions of Ms. Leticia H. Nolasco and Ms. Nancy A. Turner.

This work was supported by National Heart, Lung, and Blood Institute grants HL-31588, HL-35387, HL-18584, and Robert A. Welch Foundation grant C-938.

\section{References}

1. Hoover, R., R. Rubin, G. Wise, and R. Warren. 1979. Adhesion of normal and sickle erythrocytes to endothelial monolayers. Blood. 54:872-876.

2. Hebbel, R. P., O. Yamada, C. F. Moldow, H. S. Jacob, J. G. White, and J. W. Eaton. 1980. Abnormal adherence of sickle erythrocytes to cultured vascular endothelium: possible mechanism for microvascular occlusion in sickle cell disease. J. Clin. Invest. 65:154-160.

3. Hebbel, R. P., M. A. B. Boogaerts, J. W. Eaton, and M. H. Steinberg. 1980. Erythrocyte adherence to endothelium in sickle-cell anemia: a possible determinant of disease severity. $N$. Engl. J. Med. 302:992-995.

4. Mohandas, N., and E. Evans. 1985. Sickle erythrocyte adherence to vascular endothelium: morphologic correlates and the requirement for divalent cations and collagen-binding plasma proteins. J. Clin. Invest. 76:1605-1612.

5. Smith, B. D., and P. L. La Celle. 1986. Erythrocyte-endothelial cell adherence in sickle cell disorders. Blood. 68:1050-1054.

6. Barabino, G. A., L. V. McIntire, S. G. Eskin, D. A. Sears, and M. Udden. 1986. Rheological studies of erythrocyte-endothelial cell interactions in sickle cell disease. In Pathophysiological Aspects of Sickle Cell Vaso-Occlusion. R. Nagel, editor. Alan R. Liss, Inc., New York. 113-127.

7. Ginsburg, D., R. I. Handin, D. T. Bonthron, T. A. Donlon, G. A. P. Bruns, S. A. Latt, and S. H. Orkin. 1985. Human von Willebrand factor ( $\mathrm{vWF}$ ): isolation of complementary DNA (cDNA) clones and chromosomal localization. Science (Wash. DC). 228:1401-1406.

8. Nachman, R., R. Levine, and E. A. Jaffe. 1977. Synthesis of factor VIII antigen by cultured guinea pig megakaryocytes. J. Clin. Invest. 60:914-921.

9. Jaffe, E. A., L. W. Hoyer, and R. L. Nachman. 1973. Synthesis of antihemophilic factor antigen by cultures of human endothelial cells. J. Clin. Invest. 52:2757-2764.

10. Hoyer, L. W., and J. R. Shainoff. 1980. Factor VIII-related protein circulates in normal human plasma as high molecular weight multimers. Blood. 55:1056-1059.
11. Turitto, V. T., H. J. Weiss, T. S. Zimmerman, and I. I. Sussman. 1985. Factor VIII/von Willebrand factor in subendothelium mediates platelet adhesion. Blood. 65:823-831.

12. Moake, J. L., N. A. Turner, N. A. Stathopoulos, L. H. Nolasco, and J. D. Hellums. 1986. Involvement of large plasma von Willebrand factor (vWF) multimers and unusually large vWF forms derived from endothelial cells in shear stress-induced platelet aggregation. J. Clin. Invest. 78:1456-1461.

13. Coller, B. S., E. I. Peerschke, L. E. Scudder, and C. A. Sullivan. 1983. Studies with a murine monoclonal antibody that abolishes ristocetin-induced binding of von Willebrand factor to platelets: additional evidence in support of GPIb as a platelet receptor for von Willebrand factor. Blood. 61:99-110.

14. Loscalzo, J., A. Inbal, and R. I. Handin. 1986. von Willebrand protein facilitates platelet incorporation in polymerizing fibrin. J. Clin. Invest. 78:1112-1119.

15. Plow, E. F., R. P. McEver, B. S. Coller, V. L. Woods, Jr., G. A. Marguerie, and M. H. Ginsberg. 1985. Related binding mechanisms for fibrinogen, fibronectin, von Willebrand factor, and thrombospondin on thrombin-stimulated human platelets. Blood. 66:724727.

16. Parker, R. I., and H. R. Gralnick. 1986. Identification of platelet glycoprotein IIb/IIIa as the major binding site for released plateletvon Willebrand factor. Blood. 68:732-736.

17. Plow, E. F., M. D. Pierschbacher, E. Ruoslahti, G. A. Marguerie, and M. H. Ginsberg. 1985. The effect of Arg-Gly-Asp-containing peptides on fibrinogen and von Willebrand factor binding to platelets. Proc. Natl. Acad. Sci. USA. 82:8057-8061.

18. Loftus, J., E. F. Plow, R. Pytela, M. Pierschbacher, J. J. Ryckwaert, E. Ruoslahti, and M. Ginsberg. 1986. Immunochemical and structural comparison of GPIIb-IIIa and the vitronectin receptor. Circulation. 74:II-63. (Abstr.)

19. Sporn, L. A., V. J. Marder, and D. D. Wagner. 1986. Inducible secretion of large, biologically potent von Willebrand factor multimers. Cell. 46:185-190.

20. Hong, S. L., M. J. Weinstein, and J. L. Moake. 1983. Von Willebrand factor multimer forms produced by human endothelial cells. Blood. 62:286a. (Abstr.)

21. Ruggeri, Z. M., P. M. Mannucci, R. Lombardi, A. B. Federici, and T. S. Zimmerman. 1982. Multimeric composition of factor VIII/ von Willebrand factor following administration of DDAVP: implications for pathophysiology and therapy of von Willebrand's disease subtypes. Blood. 59:1272-1278.

22. Ruoslahti, E., E. Engvall, and E. G. Hayman. 1981. Fibronectin: current concepts of its structure and functions. Coll. Res. 1:95-128.

23. Jaffe, E. A., and D. F. Mosher. 1978. Synthesis of fibronectin by cultured endothelial cells. J. Exp. Med. 147:1779-1791.

24. Patel, V. P., A. Ciechanover, O. Platt, and H. F. Lodish. 1985. Mammalian reticulocytes lose adhesion to fibronectin during maturation to erythrocytes. Proc. Natl. Acad. Sci. USA. 82:440-444.

25. Brittenham, G. M., A. N. Schechter, and C. T. Noguchi. 1985. Hemoglobin S polymerization: primary determinant of the hemolytic and clinical severity of the sickling syndromes. Blood. 65:183-189.

26. Kaul, D. K., M. E. Fabry, and R. L. Nagel. 1986. Vaso-occlusion by sickle cells: evidence for selective trapping of dense red cells. Blood. 68:1162-1166.

27. Thorell, L., and B. Blomback. 1984. Purification of the factor VIII complex. Thromb. Res. 35:431-450.

28. Turitto, V. T. 1982. Blood viscosity, mass transport, and thrombogenesis. Prog. Hemostasis Thromb. 6:139-177.

29. Counts, R. B. 1975. Solid-phase immunoradiometric assay of factor-VIII protein. Br. J. Haematol. 31:429-436.

30. Ruggeri, Z. M., and T. S. Zimmerman. 1981. The complex multimeric composition of factor VIII/von Willebrand factor. Blood. 57:1140-1143. 
31. Moake, J. L., J. J. Byrnes, J. H. Troll, C. K. Rudy, M. J. Weinstein, N. M. Colannino, and S. L. Hong. 1984. Abnormal VIII: von Willebrand factor patterns in the plasma of patients with the hemolytic-uremic syndrome. Blood. 64:592-598.

32. Laurell, C.-B. 1966. Quantitative estimation of proteins by electrophoresis in agarose gel containing antibodies. Anal. Biochem. 15:45-52.

33. Morrison, D. F. 1983. Applied Linear Statistical Methods. Prentice-Hall, Inc., Englewood Cliffs, NJ. 281-299.

34. Mosher, D. F. 1982. Fibronectin: relevance to hemostasis and thrombosis. In Hemostasis and Thrombosis: Basic Principles and Clinical Practice. R. W. Colman, J. Hirsh, V. J. Marder, and E. W. Salzman, editors, J. B. Lippincott Co., Philadelphia. 174-184.

35. Mackie, I., H. Bull, and M. Brozovic. 1980 . Altered factor VIII complexes in sickle cell disease. Br. J. Haematol. 46:499-502.
36. Patel, V. P., and H. F. Lodish. 1986. The fibronectin receptor on mammalian erythroid precursor cells: characterization and developmental regulation. J. Cell Biol. 102:449-456.

37. Charo, I. F., L. A. Fitzgerald, B. Steiner, S. C. Rall, Jr., L. S. Bekeart, and D. R. Phillips. 1986. Platelet glycoproteins IIb and IIIa: evidence for a family of immunologically and structurally related glycoproteins in mammalian cells. Proc. Natl. Acad. Sci. USA. 83:83518355.

38. Sprandio, J. D., P. Thiagarajan, S. S. Shapiro, and R. R. Montgomery. 1986. Cultured human umbilical vein endothelial cells (HUVEC) contain a membrane glycoprotein (Gp) immunologically related to platelet GpIb. Blood. 68:357a. (Abstr.)

39. Frangos, J., J. L. Moake, and L. V. McIntire. 1986. Evidence for an endothelial cell-dependent vWF processing activity in plasma. Clin. Res. 34:656a. (Abstr.) 